\title{
First report of powdery mildew caused by Podosphaera xanthii on Matricaria chamomilla in Korea
}

\author{
In-Young Choi ${ }^{1}$. Sun-Hee Hong ${ }^{2} \cdot$ Yong-Ho Lee ${ }^{2} \cdot$ Hyeon-Dong Shin ${ }^{3}$ (i)
}

Received: 17 September 2021 / Accepted: 7 January 2022 / Published online: 14 January 2022

(c) The Author(s) under exclusive licence to Società Italiana di Patologia Vegetale (S.I.Pa.V.) 2022

Keywords Chasmothecia - German chamomile · Identification · ITS sequence

Matricaria chamomilla L. (Asteraceae), known as German chamomile, is popular in Korea for medicinal and ornamental purposes. During September and October 2019, powdery mildew symptoms on the leaves and stems of $M$. chamomilla were observed on $50 \%$ of 300 plants surveyed at an herb

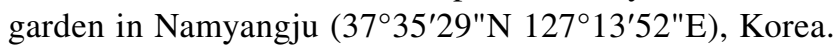
Conidiophores were cylindrical, 110-190×10-12 $\mu \mathrm{m}$ and produced conidia in chains. Conidia were ellipsoid-ovoid to doliiform, $28-40 \times 18-23 \mu \mathrm{m}$, and contained conspicuous fibrosin bodies. Dark brown chasmothecia were gregarious, partly embedded in the hyphal mat, spherical, and $85-100 \mu \mathrm{m}$ in diameter. Appendages were hyphoid, 1-4septate, and brown but paler upwards. Each chasmothecium contained a single ascus. Asci were sessile, 8 -spored, and 54-70 $\times 48-56 \mu \mathrm{m}$. Ascospores were oval to subglobose, and $14-18 \times 12-15 \mu \mathrm{m}$. These characteristics were consistent with those of Podosphaera xanthii (Castagne) U. Braun \& Shishkoff (Braun and Cook 2012). To confirm the morphological identification, rDNA was extracted from the reference isolate KUS-F31455 deposited at Korea University Herbarium. PCR products were amplified using the primers ITS1F and PM6 for the internal transcribed spacer (ITS) region, and PM3 and TW14 for the large subunit (LSU) region of the rDNA. The sequences were deposited in GenBank (Accession Nos. OK161015 for ITS, OK161017 for LSU). A Blastn search using ITS and LSU sequences showed

Hyeon-Dong Shin

hdshin@korea.ac.kr

1 Department of Agricultural Biology, Jeonbuk National University, Jeonju 54896, Korea

2 Department of Plant and Environmental Science, Hankyong National University, Anseong 17579, Korea

3 Division of Environmental Science and Ecological Engineering, Korea University, Seoul 02841, Korea
99.33 to $100 \%$ similarity with P. xanthii (e.g., MF663781, MG657015 for ITS; MT826247, MT919354 for LSU). Several species of Podosphaera on Matricaria spp. have been recorded from Europe, North America, Egypt, and Japan (Farr and Rossman 2021). Recently, ITS sequence of a powdery mildew on M. chamomilla in Iran (MF663781) clustered with P. xanthii (Khodaparast 2016). To our knowledge, this is the first report of powdery mildew disease associated with P. xanthii on M. chamomilla in Korea.

Funding This work was supported by Korea Institute of Planning and Evaluation for Technology in Food, Agriculture and Forestry (IPET) through Crop Viruses and Pests Response Industry Technology Development Program, funded by Ministry of Agriculture, Food and Rural Affairs (MAFRA) (Project No. 320043-05).

\section{Declarations}

Informed consent The manuscript is new and not being considered elsewhere. All authors have approved the submission of this manuscript.

Conflict of interest The authors declare no conflict of interest.

\section{References}

Braun U, Cook RTA (2012) Taxonomic manual of the Erysiphales (Powdery Mildews), CBS Biodiversity Series No. 11. CBS, Utrecht, The Netherlands

Farr DF, Rossman AY (2021) Fungal Databases, U.S. National Fungus Collections, ARS, USDA. Accessed September 162021

Khodaparast SA (2016) Molecular identification of some anamorphic powdery mildews (Erysiphales) in Guilan province, north of Iran. Mycologia Iranica 3:127-133

Publisher's Note Springer Nature remains neutral with regard to jurisdictional claims in published maps and institutional affiliations. 